International Journal of English Literature and Social Sciences
Vol-6, Issue-4; Jul-Aug, 2021

Peer-Reviewed Journal

\title{
Impact of Urbanization on a Lambada Tribe in Telangana
}

\author{
Dr. M.Vandana Roshni
}

Received: 10 Jul 2021; Received in revised form: 12 Aug 2021; Accepted: 22 Aug 2021; Available online: 31 Aug 2021

(C)2021 The Author(s). Published by Infogain Publication. This is an open access article under the CC BY license

(https://creativecommons.org/licenses/by/4.0/).

\begin{abstract}
The Lambada tribal community can be found are all over the state of Telangana. The community has a population of 20, 46,117. The languagethat they members speak is known as 'Gour Boli'.It speaks volumes about the resilience of this community, which has fully grown out of the totally unjust tag of a 'criminal tribe' to emerge as a very vibrant and colourful tribe, and enriched and added luster to the cultural fabric of India.The study will explore the various facets about the culture and traditions of the Lambadas.The focus will be on the well laid down norms and practicesof this community...To present amore balanced picture, the adverse effect of Urbanization in areas like Cultural change,dres, life cycle rituals, and celebration of festivals, will also be highlighted.

It has understood that urbanization has brought out both positive and negative changes in the community.The dilemma of tradition vs. modernity can be resolved by synergizing the cultural elements that the Lambadas continues to changebrought by modernity.
\end{abstract}

Keywords - Lambada, Telangana, Resilience, Criminal Tribe, Vibrant, cultural fabric, pagan, savage, Modernisation, animistic.

\section{INTRODUCTION}

"The English word tribe, which has been derived from Latin word 'tribus', which stands for a certain type of familiar and supporting organization, living in allthese societies"In India, tribal culture has to be understood in terms of its uniqueness. Warm hospitality, simple ways of living, and high degree of respect for the elders and consideration for women are some of the traits that mark the tribal culture of India.India is lands of rich cultural diversity, withpeople of different races, religious beliefs, languages, etc., living in near total harmony .One can find tribal, or aboriginals in almost all parts of India. The present overall tribal population of India is approximately 20 million. Their culture reflects their belief in leading simple lives.Most of the Adivasi groups in India have their own gods and goddesses that reveal their close linkages with nature.Most of the tribes in India are friendly, outgoing, fun loving and are very close-knit units. Some of the tribes are patriarchal in nature, while others are matriarchal."

\section{RESEARCH METHODOLOGY}

The study is based on both primary and secondary data. The primary include: Personal interaction with a crosssection of the Lambada community. The secondary sources included books, newspaper and magazine articles, and other research papers.

\section{Hinduised Lambadas}

Once the British entrenched themselves in India, they started exploiting the Lambadas who were traders. Many Lambadas choose to settle as agriculture laborersonbarren lands. The cultural life of the Lambadas underwent a change. The community started slowly adopting or changing its religious culture to a new religious culture, adopted from the neighbouring communities. After the colonial period, the community started settling near the predominantly Teluguvillages, "which made them more 'visible'to the wider society, particularly the caste Hindu society"

"The way of interaction between the tribes and the Hindus is a process of religious 'borrowing' or syncretism. By and large, all the tribal communities are adopting the beliefs system of the Hindu Gods and goddesses into their animistic religious systems. The majority of the upper 
castes, who live in Telangana, have higher incomes, when compared to the other castes in the state. In many parts of Telangana, Reddys are biggest landlords who own acres of land. Such landlords have tended to appoint agricultural workers and servants from the economically backward communities like Dalits and Lambadas.

The culture of the Lambada community is being influenced by that of the Hindu mainstream society. People of the Lambada community have tended to stay in their unique settlements, known as "Thandas". They live approximately three to four $\mathrm{km}$ away from the mainstream village. The people from the Thandas are increasingly earning their livelihood in the nearby Hindu villages. In this process, they are being influenced by the rituals, festivals, mode of worship, language, food and dress of the Telugu Hindu community.

"The tribal community can be classified into two groups on the process of cultural change. One, those assimilated to the Hindu culture and, two, those who continue to be animistic in culture, with their own cultural practices and beliefs.

"From 1921, all the Lambadas and Adivasis were classified as 'Animists'. It was probably because of the communal politics of the time, which motivated the state officials to specify Adivasis under a separate religious category, so as to reduce the Hindu population in the state. There was strong opposition to this move by the Arya Samaj.This scheme was dropped finally in the 1941 Census. However, the Census Commissioner of Hyderabad declared Adivasi tracts as no-man's-lands. By then, the Lambadas of Telangana had started claiming their position within the Hindu fold"

As already mentioned, the Lambadas in Telangana state have culture, tradition, belief system, etc., which are quite dissimilar from those of the mainstream society.

"The communities are generally treated as, separate, outcastes and untouchables" by the larger Hindu populations in Telangana region, The Lambadas are originally a nomadic tribe which settled long before independence in different parts of the Telangana State. In rural and urban areas, most of the neighbouring communities are Hinduised Telugus. It is rather unfortunate that the Lambadas were given the rather cruel tag of 'criminal tribes' by the British rulers. This unjustified stigmatization seems to be carried forward by the village mainstream community in Telangana and also other parts of country. "The nomadic ways of life too was regarded as suspicious. Since they were difficult to be controlled, they were often termed as criminals. Even now, the practice of branding members of this community as criminals has not totally disappeared, and criminality continues to be regarded as the hereditary occupation of the Lambadas".

\section{Myth related to Cultural Change}

The Lambadas of Telangana and Andhra Pradesh stateshave been claiming themselves as a Hinduised tribe from 1985 onwards. They started regarding Mola, who was linked to Hindu mythology, as their ancestor. The Lambadas started asserting that Mola was a descendant of Lord Krishna.

The story goes like this. One day, Lord Krishna decides to return to his heavenly abode. He asks his servants to meet him in his chamber. When the servants assemble there, Krishna tells them that he has decided to depart and distribute his Gopikas (female devotees) among them. He also tells them that they can have sexual relations with the Gopikas. At that time, Mola, a servant, was absent, as he has been sent on some work. When he returns, he comes to know of what had transpired and is upset that no Gopikashas been kept for him. He reproaches Krishna for this. Lord Krishna consoles him by saying that he has kept aside Radha, his most belovedGopikas, for him. But Krishna tells Mola that because Radha is sacred and his (Krishna's) beloved Gopikas, Mola should not have a sexual relationship with her, and should take great care of her. Mola gladly accept Radha with this condition. From then onwards, Mola and Radha start living as partners, without any physical relations.

The cultural change in the Lambada community is being accelerated by factors like: Adoption, Acculturation, and Assimilation. TheLambada community of Telangana can be said to be adopting the culture of the mainstream community, in order to be integrated into the mainstream, "where a low Hindu caste, or a tribal group, tends to change its traditions, rites, beliefs and way of life in the direction of a high, and habitually, twice-born caste" Adoption means nothing but change in the culture of Lambada from their traditional dress of women's skirt, chunari, and half blouse to saree, food habits, belief system and language. Also, the dress of many Lambada men has changed from dhoti and turban to simple dhoti worn by many men in the Telugu mainstream community.

"The Assimilation of any castes should be low in the group of Brahminical society and which must be inculcated in the Hindu society. In other words, a 'Hindu', in this operative sense, refers more to a member of a certain social hierarchy than to a follower of a certain religion as such. This being the case, over the centuries, non-Hindu groups living on the fringes of caste Hindu societies have been gradually absorbed into the Hindu fold as castes, generally relegated to the position of shudras or 'untouchables.' If they were artisans, they were 
transformed into laboring, or tribal, groups. They came to be regarded as Kshatriyas, in case they originally belonged to the ruling tribal groups. This process of Hinduisation, which extended over several generations, often though not necessarily always, resulted in the transformation of the local religious tradition through the incorporation of beliefs and practices associated with Brahminical 'Hinduism' "Certain low castes continue to be looked down upon as so contaminated that they may not enter the courtyard of the great temples. These castes are obligated to live by themselves on the outskirts of villages."The majority members of the community were treated by the mainstream communities as uncouth and uncivilized people." Even today, in some parts of the rural areas, the Lambadas tend to be looked down and treated as an outcaste community and treated as 'untouchables' by the mainstream community.Whensomeone from the mainstream community like Reddysand Komati's arise to the Thanda, they feel uncomfortable to take water and food from the Thanda people.

The Tribal community of Lambada is surrounded by the non-Lambada community, the mainstream people whose culture and traditions are controlled by the Brahmin priests. Before the introduction of modern means of transportation by the British rulers, the Lambadas, the inhabitants of forests, earned their livelihood by collecting forest products like wood, fruits and betelleaves, etc., and selling these in the nearest markets.

The members of Lambada community, who try to imitate the culture of the Hindu Telugu speaking community, are adopting features like Hindu-Telugu names (Shiva, Ganesh, Ravi, etc.) and Telugu rituals, festivals, and dress, language and food habits of the mainstream Hindu community.Such a phenomenon is more pronounced in the case of the educated Lambadas, who come into greater contact with the Telugu-speaking community. Earlier, such changes were more predominant in urban areas, but now, even Lambadas in rural areas, are being increasingly drawn towards the cultural practices of people of other communities.

One can find increasing instances of Tulsiplants appearing in front of houses in the Thandas. Pujas to Hindu Gods are being performed and temples of Hindu Gods and goddesses are being constructed in the Thandas. Also, more and more Lambadas have started visiting Hindu temples. The members of the Lambada community who have been greatly influenced by the Hindu cultural practices are known as Hindu Lambadas. These people celebrate all the rituals like members of the mainstream community.

\section{Puberty Ritual}

Due to the cultural contact with the mainstream communities, the Lambadas have started to organise functions, when their girls attain puberty. The near and dear ones are invited to celebrate the event. The particular girl child is not allowed to go out of the house for eleven days. On the last day, a function is organised. They invite Brahmin priests to conduct the puja. This is followed by lunch.

\section{Marriage Ceremony of Hinduised Lambadas}

The marriage rituals, adapted from the Telugu culture, are now confined to a single day process of marriage. The present system is an admix of Lambada and Hindu systems. One major change has been increasing trend towards the "dowry system". Earlier, it was considered as bride price. Now the dowry is in terms of cash, gold ornaments, property, and land, etc., according to the status of the family. Depending on the financial condition of the parents of the bride, the marriage rituals are performed, either in their houses, or in function halls.

Even the attire of the bride and bridegroom is changing under the increasing influence of the Hindu Telugu culture. Now, there is an increasing trend for the bride to wear a saree and the bridegroom, kurta pyjama.In both urban and rural areas, Hindu Brahmin priests are increasingly 'presiding over' the marriage rituals of the Lambadas. The bride and bridegroom are made to sit towards the east direction and the priest chants the mantras. The most important symbol of marriage, the mangalsutra, is tied by the groom to the bride's neck and jilakara bellam (a paste of cumin seedsand jaggery) is placed on the head of the bride according to the Telugu tradition.

\section{Cradle Ceremony}

This is ritual is celebrated on the 21 st day of the child's birth. Earlier, there were no celebrations on such occasions, but, today, after adaptation of the mainstream customs and culture, the community has started to celebrate this ceremony in the same manner as the Telugu community.

\section{Festival Celebration}

In Telangana, the Lambada community is being greatly influenced by the practice of Hindu festivals. Along with animistic celebrations, the Lambada community has started giving importance to the Hindu festivals. In the urban areas of Telangana, Lambadas are celebrating Hindu festivals such as "Bonalupanduga, Ganesh Chathurthi, Varalaxmi Varatham, Raksha Bandhan, Karthikamasam, Sankranthi and Shivratri. Lambadas residing in the cities are tending to give a lot of importance to the celebration of these festivals. 


\section{Balaji}

There is great impact of Balaji on the lives of the nomadic Lambadas. Many of them go to Tirupati every year to have a darshan of Lord Venketshwara and perform puja to the Lord after they return home. They invite the inhabitants of the Thanda for the puja. The method of invitation is called 'Hawk Marno'. The devotees beseech Balaji in the following words:

\section{Saives Maraj Panta, Polamne bharkatdesh}

Ye Balaji Bhagwan, hamare BAL bacha re,

Jeev, Janvar rethi, en dhakh dal sen saives Maharaj,

Bhar por rahkades maharajSaives Maraj

\section{Translation}

“O! God Balaji, Protect us from all bad things and make us prosperous to lead a new way of life and protect us from famine and drought conditions. Please also bless us for thewellbeing of our children."

The above said narration points out that Lambadas prefer the extreme stage of worship in the form of sacrifice to the plain process of devotion. However, it is an established fact that they believe more in sacrifice and that plain worship is an extension of their worship. Their canvas of worship has expanded from nature and mythic deities to their local clanic ones. Anyway, they

Believe much in nature and power. There have been also ascetics and divine females in the Lambada community about whom many more myths are prevalent. The Lambadas seem to be more attracted towardsLord Krishna and his miracles. No religious rites and practices are regarded as complete without the folklores. At the same time, they are fond of religious myths and sayings. There are two sorts of songs among them. One of them is related to the devotion and worship and theysecond one pertainsto narration. The Lambadas get engrossed while singing these songs, particularly those belonging to marriage or religious rites. The very life of Lambadas is governed and inspired by these songs. Sometimes it is felt that religion cannot be separated from the social lives of Lambadas. Their original tendencies are reflected everywhere. As far as their religious life is concerned, this reflects fearfulness to God, gratitude and devotion.

\section{Hanuman}

He is a very popular God for the Hinduised Lambadas. He is also known as "The monkey god of Hindus". Lambadas worship this monkey God (Hanuman) in their own style and there is a myth related to "Vaali and Sugriva."

The Lambadas of Nalgonda and Mahboobnagar Districts pay their tribute to Lord Hanuman. The temple is located in the 'Nallamala' forest. Tribal communities, like the
Chenchus, Koyas, and Lambadas, can be seen near the temple, located in village Madhemudgu of Mahboobnagar District and is at a distance of $60 \mathrm{~km}$ from the Srisailam Temple. This place is considered sacred for the Hinduised Lambadas of this area. The people pay their annual tribute every year and it is a belief of the Lambada people, whoever visits this place has to spendthe night thereand perform puja to Lord Hanuman. The puja is performed by a male person only and he prepares prasadam without using a stove. He uses only firewood. On the flame, the pan is kept and maida atta rotis andpancakes are prepared from jaggery and ghee. After performing the puja, they start their journey to Srisailam and pay their tribute to Lord Shiva.

\section{CONCLUSION}

While Urbanization and Modernization shaken upthe traditional Lambada milieu to a considerable extent. From the above discussion so far is that the Lambadas have continued to remain a very vibrant and dynamic community. They have been very proud of their cultural ethos, traditions and customs. Unlike the dinosaurs, which became extinct because of their poor adaptability to the rapid environmental changes, the Lambadas have very valiantly withstood the forces that operated against them. When the introduction of the road and railways system threatened their occupation of transportersof goods, they adopted more settled occupations like agriculture. This enabled them to evolve a culture of their own which grew from strength to strength.Today, the Lambada culture is under severe stress.

\section{REFERENCES}

[1] Bhukya, Bhangya. Cultural History of Lambada Tribes in Modern Andhra, Hyderabad: M.Phil. Dissertation. University of Hyderabad, 1998.Print

[2] Bhangya. Bhukya: Subjugated Nomads: The Lambadas under the rule of the Nizams: Orient Blackswan Pvt Ltd: 2010

[3] Bixlay Kumar Rai. The Tribal Culture of India, Concept Publishing Company, New Delhi 1985.

[4] Chinniya Naik, B. Banjara Charitra Samskruthi- Pragathi (Telugu: Banjara's History, Culture - Development). Anantapur: Hathiram Bhavaji Publication, 1998.

[5] Devy, G.N. A Nomad Called Thief Reflections on Adivasi Silence. New Delhi: Orient Longman, 2006.Print.

[6] Gonanayak, M. "Sugali Samskruthi-Bhasha Sahityalu". Diss.Anantapur: Srikrishnaraya Vishvavidyalayam, 1993. Print.

[7] ---. Sugalisamskruthi-Bhashasahityalu. Hyderabad: Padmasri Graphiks, 2002.Print.

[8] Hardiman. David. The Coming of the Devi: Adivasi Assertion in Western India. New Delhi: Oxford University 
Press 1987.

[9] Hasan, Mushirul. 1991. Competing Symbols and Shared Code: Inter-Community Relations in Modern India. In Anatomy of a Confrontation: The Babri Masjid, Ram Janmabhumi Issue, Ed. SarvepalliGopal. New Delhi: Penguin Books.

[10] Hasan.Zoya. 2009. Politics of Inclusion: Castes, Minorities, and Affirmative Action. New Delhi: OUP.

[11] ----'Lambadas: Changing Cultural Patterns', Economic and Political Weekly, $20^{\text {th }}$ April, 2000.

[12] MrinalMiri. Continuity and Change in Tribal Society (New Delhi: Elegant Printers, 1993).

[13] Naik, D. B. The Art and Literature of Banjara Lambanis: A Socio-Cultural Study. New Delhi: Abhinav Publication, 2000 . 